\title{
Aggregate Disturbances, Monetary Policy, and the Macroeconomy: The FRB/US Perspective
}

David Reifschneider, Robert Tetlow, and John Williams, of the Board's Division of Research and Statistics, prepared this article.

The U.S. economy is continually buffeted by disturbances originating both within and outside our borders. To assess the influence of such events on employment, inflation, and other measures of macroeconomic performance, economists often use models of the economy-systems of mathematical equations describing the interactions among various measures of activity in the markets for labor, goods, and financial instruments. Although no model can replicate in full detail the complex behavior of the real world, one can construct models that are consistent with both economic theory and historical data. Such models shed light on the way the economy works and how it responds to disturbances and policy actions that are similar to those encountered historically.

The FRB/US model of the U.S. economy is maintained at the Federal Reserve Board for use in policy analysis and forecasting. With FRB/US, the Board's staff can gauge the likely consequences of specific events through simulation analysis-computational "what-if" exercises in which the model is used to predict the outcomes from alternative assumptions regarding fiscal and monetary policy, international conditions, and so forth. In a similar manner, the staff can use model simulations to assess possible implications for economic performance of the full range of disturbances likely to be experienced over extended periods of time.

This article examines the properties of the FRB/US model and the ways in which they shape the model's predictions. To a large extent, the discussion centers on the monetary transmission mechanism-the chain of relationships embedded in the model that describe how monetary policy actions influence financial markets and, in turn, aggregate output and inflation. The quantitative nature of this mechanism is illustrated by estimates of the effect of movements in interest rates and other factors on spending in different sectors and by simulations of the effect of a change in the stance of policy on the economy as a whole.

After the discussion of the transmission mechanism, the article considers the ways in which mone- tary policy influences the macroeconomic consequences of specific events in the FRB/US model by showing how the predicted effects of selected disturbances change under alternative policy responses. Because these disturbances - a decline in the value of the stock market, a period of unexpectedly rapid wage growth, and an adverse shock to the productivity of American firms and workers-differ in their implications for output and inflation, they illustrate some of the choices faced by policymakers in the context of the model. In the final section of the article, these choices are summarized in terms of policy frontiers that show how, past some point, reductions in the variability of inflation are obtained only through increases in the variability of output.

\section{PROPERTIES OF THE FRB/US MODEL}

FRB/US is what is often called a New Keynesian model because of the assumptions it incorporates. In the model, households and firms are forwardlooking - that is, they base their decisions on the income and sales, financial conditions, and prices that they expect for the future. However, rather than being instantaneous, the response to changes in these fundamental factors is gradual because capital installation costs, contracts, and other considerations create significant frictions that slow the process. For this reason, the failure of markets to clear quickly after disturbances to the economy can result in periods of over- or under-utilization of labor and capital resources (see box "An Overview of the FRB/US Model").

According to the viewpoint embedded in the model, monetary policy can mitigate these swings in aggregate resource utilization by altering financial market conditions and thereby exerting an indirect influence on output and employment in the short term and on inflation over the longer term. In FRB/US, policymakers alter financial conditions by changing the short-term interest rate under the control of the Federal Reserve- the federal funds rate. Current and anticipated changes in this rate influence prices and rates of return on various financial assets, including bonds and corporate equities, and on foreign exchange. 
Changes in these financial conditions in turn influence spending by households and firms and, by altering resource utilization in labor and product markets, affect the rate of inflation. (For alternative views on how monetary policy may influence the economy, see box "Other Monetary Transmission Channels.")

\section{An Overview of the FRB/US Model}

Macroeconomic models sometimes differ in their predictions about the effect of a particular event on the economy, owing to differences in theoretical design, empirical specification, and degree of aggregation. For this reason, reviewing the structure of the FRB/US model is useful for understanding the model's behavior. ${ }^{1}$

The equations of FRB/US are specified in accordance with standard economic theory. In particular, households, businesses, and investors are assumed to be forward-looking in their decisionmaking as they seek to optimize their welfare. Individuals choose a path for current and future consumption that maximizes their lifetime utility, subject to a budget constraint; this assumption implies that consumer spending today is related to the present value of expected future earnings and the current value of assets. Similarly, firms maximize expected profits in hiring workers, investing in capital goods, and setting prices; this assumption implies, among other things, that the desired stock of business equipment is a function of expected sales and the cost of capital. In financial markets, investors equate expected rates of return on different assets, subject to premiums that compensate borrowers and lenders for differences in risk and liquidity.

In their decisionmaking, households and firms are assumed to face significant frictions that slow the speed at which they adjust prices and quantities to changes in fundamental economic factors. Although not explicitly incorporated into the structure of FRB/US, the sources of these frictions are varied; they include the cost of adjusting a firm's work force and physical capital, labor contracts and other agreements, and an apparent reluctance of households to change spending habits quickly. The existence of such frictions means that households and firms have an incentive to be forward-looking in their behavior because costs of adjusting spending and prices can be reduced by correctly anticipating their preferred values in the future. As a result, many decisions in the nonfinancial sectors depend not only on conditions today and in the recent past but also on the way conditions are expected to change in the near future.

1. For a more extended discussion of the FRB/US model and its uses, see Flint Brayton and Peter Tinsley, "A Guide to FRB/US: A Macroeconomic Model of the United States," Finance and Economic Discussion Series, 1996-42 (Board of Governors of the Federal Reserve System, October 1996); Flint Brayton, Eileen Mauskopf, David Reifschneider, Peter Tinsley, and John Williams, "The Role of Expectations in the FRB/US Macroeconomic Model," Federal Reserve Bulletin, vol. 83 (April 1997), pp. 227-45; and Flint Brayton, Andrew Levin, Ralph Tryon, and John B. Williams, "The Evolution of Macro Models at the Federal Reserve Board," Carnegie-Rochester Conference Series on Public Policy, vol. 47 (1997), pp. 43-81.
Expectations also play a key role in determining prices in the financial market sector of the model. However, the motivation for this dependence on expectations is somewhat different because financial decisions are assumed to be unaffected by frictions, given the negligible cost of such transactions. Rather, expectations figure prominently in this sector because the return on many financial investments is a stream of payments stretching well into the future. In FRB/US, expectations are modeled explicitly, but in a flexible manner that allows Board staff to make alternative assumptions about the amount of information available to households, firms, and investors in forming their expectations about the future course of the economy.

Because of the presence of frictions that delay the adjustment of nonfinancial variables, FRB/US belongs to a class of models often described as "New Keynesian." ${ }^{2}$ In such models, prices and quantities do not adjust quickly enough to ensure full resource utilization at all times. These models predict that the labor market, in particular, will be out of equilibrium periodically. For example, during economic downturns an unusually large percentage of the labor force may be willing to work at current wage rates but be unable to find a job. Alternatively, during periods of above-average activity, the unemployment rate may temporarily fall to a low level, and employees may be required to work a longer workweek than desired. However, these Keynesian features of FRB/US diminish over time, and in the long run, when adjustment is complete, all markets clear.

An aspect of FRB/US that is closely related to slow market adjustment is the behavior of inflation. In the model, firms seek to pay workers the value of their marginal product and to price their output as a markup over trend unit labor and energy costs. However, labor contracts and other factors create frictions that slow the speed at which wages and prices adjust to shifts in demand and supply. (Commodity prices are an exception to this behavior because they adjust quickly on world spot markets). Such "sticky-price" behavior is incorporated into the equations of FRB/US that govern the response of inflation to changes in economic conditions. An important implication of this view of the inflation process is that policy-directed changes in shortterm nominal interest rates have a temporary influence on the real rate of interest. Through this influence over real interest rates, monetary policy can affect real prices and yields on a variety of financial assets and thereby indirectly influence economic activity in various sectors of the economy.

2. For further information, see N. Gregory Mankiw and David Romer, eds., New Keynesian Economics (MIT Press, 1991). 


\section{The Influence of Policy Actions on Financial Markets}

The set of relationships linking policy actions to movements in aggregate output and inflation is commonly known as the monetary transmission mechanism. In FRB/US, the first step in this chain is the connection between two markets- that for overnight interbank loans and related short-term instruments (strongly influenced by Federal Reserve operations) and that for long-term government and corporate bonds. Specifically, these markets are linked by the expectations theory of the term structure, which states that investors seek to equalize-up to a premium to compensate for differences in risk-the yield from holding a bond to maturity with the yield expected from a sequence of short-term investments in the money market. Mathematically, the theory implies that the yield on a bond is given by the following formula:

$$
R_{t, m}=\sum_{j=0}^{m-1} \omega_{j} r_{t+j}+\varphi_{t}
$$

Here $R_{t, m}$ is the yield to maturity on an $m$-period bond; $r_{t+j}$ is the value of the overnight interbank loan rate (the federal funds rate) expected $j$ periods in the future; and the weights, $\omega_{j}$, sum to unity. As the formula shows, a bond's yield is, in part, a weighted average of the funds rate expected well into the future. The remaining term, $\varphi_{t}$, denotes the premium paid to investors to compensate for uncertainty in the future course of short-term interest rates and for the chance of default.

Given this arbitrage relationship-which is assumed to hold at all times because financial markets, with their low transaction costs, are relatively unaffected by the frictions that slow adjustment in other sectors-policy can influence long-term yields in at least two ways. First, it can alter the current value of the funds rate. By itself, however, such an action has only a minor direct influence on long-term yields because the weight on the current period's setting of the funds rate is relatively small. Second, policy can affect investors' expectations for the future course of the funds rate- an influence that is potentially quite powerful. In the FRB/US model, the

\section{Other Monetary Transmission Channels}

The discussion in the text focuses on the aspects of the monetary transmission channel explicitly incorporated in the structure of the FRB/US model. In the real world, other channels may also help transmit monetary policy actions through the economy. Here in brief are two such mechanisms that have been discussed in the economics literature: the real balance effect and the credit channel.

The Real Balance Effect. The monetary base-the sum of currency and bank reserves-makes up part of the public's financial wealth. Movements in the federal funds rate are accomplished through changes in the monetary base; for example, an increase in the federal funds rate necessitates a decrease in the monetary base. Unlike debt between private parties, for which a change in value affects only the distribution of real wealth and not its overall level, changes in the monetary base do affect the level of private wealth and therefore should, in theory, alter consumption spending. However, relative to movements in other forms of wealth, movements of the monetary base are very small in size, and thus, in reality, the real balance effect is likely to be quantitatively unimportant.

The Credit Channel. A number of economists have argued that financial markets do not function as flawlessly as depicted in the standard framework embedded in the FRB/US model. ${ }^{1}$ In particular, households and firms face significantly higher costs if funds are raised from bank loans and other outside sources than if internal cash sources are used. Moreover, banks may restrict the amount lent to limit borrowers' exposure to default risk. According to this view, when monetary policy is tight, not only do high real interest rates deter spending, but as income and profits fall, many households and firms see their savings and cash reserves diminish. Given the high cost and limited availability of outside financing, households and firms curtail spending even more than the change in interest rates implies. Although it is difficult to incorporate fully the effects of such credit market imperfections into a macroeconomic model like FRB/US, in two spending categories allowance is made for such effects. For a portion of householdsestimated to account for about 10 percent of aggregate consumption-consumer outlays move one-for-one with current income. Similarly, a portion of business investment in equipment depends on current profits, capturing the reliance of many firms on internal funds. More generally, household spending is estimated to be more procyclical than standard theory would imply, perhaps because of the effects of the credit channel.

1. For a recent review of this literature, see Ben S. Bernanke, "Credit in the Macroeconomy," Federal Reserve Bank of New York Quarterly Review (Spring 1993), pp. 50-70. For an empirical evaluation of different views of the monetary transmission channels, see Christina D. Romer and David H. Romer, "New Evidence on the Monetary Transmission Mechanism," Brookings Papers on Economic Activity, vol. 1 (1990), pp. 149-213. 
public expects policymakers to respond to changes in economic conditions in a systematic manner, raising the funds rate when output is above potential and inflation is high and lowering rates when output is below potential and inflation is low. In forming their expectations, households, firms, and investors use this expected policy response to guide their forecasts not only of the future course of interest rates but also of output, inflation, and other macroeconomic variables. ${ }^{1}$ (For additional information on monetary pol-

1. Further information on the treatment of expectations in the FRB/US model can be found in Flint Brayton and others, "The Role of Expectations in the FRB/US Macroeconomic Model," Federal Reserve Bulletin, vol. 83 (April 1997), pp. 227-45.

\section{How Does the Federal Reserve Set the Funds Rate?}

Throughout this article, monetary policy actions are characterized as setting the nominal federal funds rate- the interest rate that banks pay to each other for overnight loans of reserves held in the Federal Reserve System. In fact, the Federal Reserve does not directly control the federal funds rate; instead, the funds rate is a market rate determined by the supply and demand for reserves. The Federal Reserve uses open market transactions-buying and selling Treasury securities-to expand or contract the supply of reserves. By choosing the right supply of reserves to the banking system, the Federal Reserve can effectively keep the funds rate near its desired level. ${ }^{1}$

An alternative representation of monetary policy procedures is one in which the Federal Reserve, instead of choosing a level for the funds rate, strives to keep the money supply near a target level. If the reserves-tomoney multiplier were stable, the money supply target would imply a particular level for the supply of reserves. If the demand for both money and reserves were also stable, the money supply target would be associated with a particular level of the federal funds rate. Therefore, targeting the money supply and targeting the federal funds rate need not be fundamentally different approaches. In practice, however, substantial disturbances to money demand occurred as a result of financial deregulation during the early 1980 s and financial innovation in the early 1990s. Current discussions of monetary policy and Federal Reserve practice therefore focus on the direct setting of the federal funds rate. ${ }^{2}$

1. For a detailed account of open market operations, see Ann-Marie Meulendyke, U.S. Monetary Policy and Financial Markets (Federal Reserve Bank of New York, 1989), and "Open Market Operations during 1997," Federal Reserve Bulletin, vol. 84 (July 1998), pp. 517-32.

2. See Joshua N. Feinman and Richard D. Porter, "The Continuing Weakness in M2," Federal Reserve Board Finance and Economics Discussion Series 1992-209 (September 1992). icy operations, see box "How Does the Federal Reserve Set the Funds Rate?")

Similar asset-pricing formulas, based on the same principle of equalizing risk-adjusted expected rates of return across investments, link the value of corporate equities to the yield on bonds and expectations of future corporate earnings. In addition, arbitrage across international markets implies that variations in the return on investments in the United States cause changes in the foreign exchange value of the dollar.

\section{The Influence of Financial Market Conditions on Spending}

Changes in financial conditions, whether or not driven by shifts in the stance of monetary policy, are an important factor in the spending decisions of households and firms. For example, swings in interest rates can greatly affect the cost of financing purchases of goods on credit. In the case of the stock market, equity price movements have historically been a large component of changes in household wealth, which alter the desired level of consumer spending. Finally, changes in the foreign exchange value of the dollar alter the price of domestically produced goods relative to the price of products produced abroad and thereby influence the volume and direction of foreign trade.

These financial effects manifest themselves in FRB/US in several ways. For example, the stock of capital equipment that firms hold is sensitive to movements in the relative price of that stock, which includes the cost of raising funds in both the bond and the equity markets. These financing costs are related to expected real yields on both types of assets - that is, the nominal yield that must be paid to an investor for holding a bond or a corporate equity less the average rate of inflation expected to prevail over the holding period. Similarly, movements in real mortgage and bank loan rates influence the desired level of the housing stock and consumer holdings of motor vehicles and other durable goods.

We use the model to derive the quantitative importance of these financial effects for different categories of stocks and spending by computing the response of individual sectors to changes in interest rates, wealth, and the exchange rate in isolation from the rest of the economy (table 1). In particular, no allowance is made here for feedback effects - that is, for a simulated change in sectoral spending to alter, in turn, the original change in financial conditions. This type of calculation, typically dubbed partial-equilibrium analysis, provides a direct measure of the quantita- 
1. Partial-equilibrium response of capital stocks and private spending to changes in financial conditions, with other factors constant

Percent

\begin{tabular}{|c|c|c|c|c|}
\hline \multirow{2}{*}{$\begin{array}{l}\text { Category of stock } \\
\text { and spending }\end{array}$} & \multicolumn{4}{|c|}{ Response in level at end of year } \\
\hline & 1 & 2 & 3 & 15 \\
\hline \multirow{5}{*}{$\begin{array}{l}\text { Capital stocks } \\
\text { Consumer durable goods } \ldots \ldots \\
\text { Housing } \ldots \ldots \ldots \ldots \ldots \ldots \\
\text { Producers' durable } \\
\quad \text { equipment } \ldots \ldots \ldots \ldots \ldots\end{array}$} & \multicolumn{4}{|c|}{1 percentage point decrease in interest rates } \\
\hline & & & & \\
\hline & .3 & .7 & .8 & .8 \\
\hline & .1 & .3 & .5 & 1.3 \\
\hline & .1 & .5 & 1.0 & 4.0 \\
\hline \multirow{5}{*}{$\begin{array}{l}\text { Private investment spending } \\
\text { Consumer durable goods } \ldots \ldots \\
\text { Housing }, \ldots \ldots \ldots \ldots \ldots \\
\text { Producers' durable } \\
\quad \text { equipment }{ }^{1} \ldots \ldots \ldots \ldots\end{array}$} & & & & \\
\hline & 1.7 & 1.7 & 1.3 & .8 \\
\hline & 4.8 & 6.8 & 5.7 & 1.3 \\
\hline & 1.3 & 3.1 & 3.8 & 4.0 \\
\hline & \multicolumn{4}{|c|}{20 percent increase in stock market wealth } \\
\hline \multirow{4}{*}{$\begin{array}{l}\text { Private spending } \\
\text { Consumer durable goods } \ldots \ldots \\
\text { Housing } \ldots \ldots \ldots \ldots \ldots \ldots \\
\text { Consumer spending on } \\
\quad \text { nondurable goods and } \\
\quad \text { services } \ldots \ldots \ldots \ldots \ldots \ldots\end{array}$} & & & & \\
\hline & 2.4 & $\begin{array}{l}1.3 \\
3.5\end{array}$ & $\begin{array}{l}1.1 \\
2.9\end{array}$ & $\begin{array}{l}.6 \\
.6\end{array}$ \\
\hline & .2 & .4 & .5 & .6 \\
\hline & \multicolumn{4}{|c|}{6 percent depreciation of the dollar } \\
\hline Exports & 1.7 & 4.8 & 5.5 & 5.7 \\
\hline Imports & -1.1 & -3.5 & -3.8 & -3.7 \\
\hline
\end{tabular}

1. Includes effect of a 1 percentage point fall in the rate of return on equity.

tive importance of these parts of the transmission mechanism.

In the FRB/US model, a decrease in all interest rates-with inflation, income, and other factors held constant-boosts the desired stocks of consumer durable goods, business equipment, and residential structures by lowering the relative cost of investment goods (top portion of table 1). Because of frictions that make rapid installation of new capital costly, households and firms do not instantaneously adjust capital stocks to the new long-run desired levels. Instead, adjustment is gradual, especially in the case of producers' durable equipment and housing, for which only a fraction of the long-run rise in the capital stock is in place at the end of three years. ${ }^{2}$

The gradual adjustment of stocks does not imply that associated investment spending - that is, expenditures on new equipment and structures intended to cover depreciation of the existing stocks as well as any desired net increments to stocks-is slow to respond to a sustained change in interest rates. In fact, the opposite is true: The percentage increase in

2. In FRB/US, movements in interest rates have no direct effect on two other categories of investment-nonresidential structures and inventories. Although such investment should, in theory, depend on interest rates, the empirical evidence for such interest sensitivity is weak. investment outlays for all three categories is substantial in the first year, with spending rising further over the next year or two and even climbing above its long-run percentage change in the case of consumer durable goods and housing. Such a hump-shaped pattern in the response of investment flows (as opposed to the corresponding stocks) is called the accelerator effect. It arises because gross investment spending is typically small in relation to the size of the capital stock, implying that a given percentage change in stocks, if it is to be achieved rapidly, requires a much larger percentage movement in investment outlays. This phenomenon is particularly important for housing, where the ratio of investment outlays to the capital stock is so low that it would take an increase of approximately 25 percent in spending to raise the capital stock 1 percent within a year.

As noted previously, financial conditions should have a major influence on private spending through wealth effects because the desired level of consumer spending depends, in part, on the current value of net household assets. An important component of the latter is corporate equity, whether held directly or owned indirectly in the form of mutual fund shares and pension fund reserves. Such stock market wealth (which currently accounts for roughly one-third of household net worth) is highly variable over time and has a tendency to rise whenever real long-term interest rates fall, because of arbitrage between the bond and stock markets. According to the model's pricing formula for the stock market, a 1 percentage point decrease in the real yield on bonds should be accompanied by a 20 percent increase in the value of corporate equity, all else being equal. ${ }^{3}$ Such a boost to wealth stimulates the various components of household spending by an appreciable amount, particularly in the short run for investment expenditures (middle portion of table 1). ${ }^{4}$

3. In equilibrium, the dividend-price ratio for equities is approximately equal to $r+\theta-g$, where $r$ is the expected yield on bonds, $\theta$ is a premium paid to investors to compensate them for the greater riskiness of equity, and $g$ is the expected growth rate of dividends. Because the historical mean of $r+\theta-g$ is about 5, a 1 percentage point increase in the yield on bonds reduces equity prices on average by one-fifth, or 20 percent, all else being equal. Although in theory the sensitivity of stock prices to a change in interest rates should shift as $r, \theta$, and $g$ move over time, this nonlinear effect is ignored in the FRB/US model.

4. Wealth effects such as these are often described in terms of how much an additional dollar of wealth increases consumer spending. In the FRB/US model, an extra dollar of stock market wealth increases spending on average about $3 \frac{1}{2} 2$ cents in the long run. However, because the elasticity of spending with respect to wealth is constant in the model, at the present high valuation of the stock market the estimated wealth effect is closer to 2 cents. 
The final major influence of financial markets on spending occurs through the market for foreign exchange. As with stock prices, the exchange value of the dollar with respect to foreign currencies fluctuates widely over time. However, arbitrage across international money and bond markets causes movements in the exchange rate to be correlated with changes in U.S. interest rates. A version of this relationship, called the uncovered interest parity condition, implies that a 1 percentage point fall in real domestic long-term interest rates should produce an immediate 6 percent depreciation of the dollar, all else being equal. ${ }^{5}$ In FRB/US, such a depreciation of the dollar boosts the demand for U.S. exports almost 6 percent by lowering the price of American goods expressed in a weighted average of foreign currencies (bottom portion of table 1). In the same manner, depreciation of the dollar increases the domestic price of foreign-produced goods, decreasing the volume of imports almost 4 percent in the long run. In both cases, the adjustment of trade volumes is not instantaneous but is spread over two or three years.

\section{The Influence of Changes in Aggregate Income and Sales on Spending}

Changes in sectoral spending, whether caused by financial factors or other forces, alter the level of aggregate sales, output, and income. Changes in these economywide factors, in turn, further influence the spending of households and firms beyond the financial effects just described. Such general-equilibrium effects are incorporated into simulations of the full FRB/US model. However, as in the analysis of the direct effects on spending of changes in financial conditions, examining this feedback portion of the monetary transmission mechanism in a partialequilibrium framework is instructive.

Table 2 summarizes the response of different categories of private spending to a 1 percent increase in the level of aggregate income, output, and sales, with

5. Ignoring risk considerations, the uncovered interest parity condition implies that, if the expected yield on a dollar-denominated bond is higher than the yield on a bond denominated in a foreign currency, investors will hold the foreign bond only if the dollar is expected to depreciate by enough to equate the two yields when both are measured in a common currency. For this reason, when domestic interest rates rise relative to foreign rates, the dollar immediately appreciates to ensure the requisite amount of future depreciation. Under the assumption that the duration of the average bond is about six years, a 1 percentage point decrease in the spread between domestic and foreign interest rates should therefore yield a 6 percent depreciation of the dollar.
2. Partial-equilibrium response of capital stocks and private spending to a 1 percent increase in the level of aggregate income, sales, output, and wealth, with other factors constant

Percent

\begin{tabular}{|c|c|c|c|c|}
\hline \multirow{2}{*}{$\begin{array}{l}\text { Category of stock } \\
\text { and spending }\end{array}$} & \multicolumn{4}{|c|}{ Response in level at end of year } \\
\hline & 1 & 2 & 3 & 15 \\
\hline \multicolumn{5}{|l|}{ Capital stocks } \\
\hline Consumer durable goods & .2 & .6 & .9 & 1.0 \\
\hline 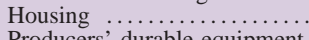 & .1 & .3 & .4 & 1.0 \\
\hline Producers' durable equipment & .1 & .4 & .8 & 1.0 \\
\hline Inventories $\ldots \ldots \ldots \ldots \ldots$ & .8 & 1.1 & 1.0 & 1.0 \\
\hline \multicolumn{5}{|l|}{ Private investment spending } \\
\hline Consumer durable goods ... & 1.5 & 2.0 & 1.7 & 1.0 \\
\hline Housing $\ldots \ldots \ldots \ldots . .$. & 3.9 & 5.7 & 4.7 & 1.0 \\
\hline Producers' durable equipment & 1.3 & 2.0 & 1.8 & 1.0 \\
\hline Nonresidential structures . & 1.1 & 1.4 & 1.3 & 1.0 \\
\hline Inventories $^{1} \ldots \ldots \ldots \ldots$ & .8 & .3 & -.1 & .0 \\
\hline \multicolumn{5}{|l|}{ Other private spending } \\
\hline Consumer nondurable goods & & & & \\
\hline $\begin{array}{l}\text { and services } \\
\text { Imports } \ldots \ldots \ldots \ldots\end{array}$ & $\begin{array}{r}.4 \\
1.9\end{array}$ & $\begin{array}{r}.7 \\
1.5\end{array}$ & $\begin{array}{r}.8 \\
1.3\end{array}$ & $\begin{array}{l}1.0 \\
1.0\end{array}$ \\
\hline
\end{tabular}

1. Change in four-quarter growth rate of inventory stocks.

prices, interest rates, and other factors held constant. Because wealth equals the present value of expected future dividends, interest, and other forms of capital income, the net worth of households has also been increased 1 percent. In these simulations, the income shift is permanent and is assumed to be immediately recognized as such by firms and households.

The table reveals an important feature of the behavior of households and firms - the speed at which the public adjusts its spending to a change in income and sales. For example, in the model the level of consumer spending depends on both income and wealth. In response to a rise in income and wealth of 1 percent, outlays on consumer nondurable goods and services would be expected to rise proportionally in the absence of any frictions slowing adjustment. However, because such impediments to rapid adjustment are estimated to be significant, this category of consumer spending rises to its new long-run level only after three or four years. ${ }^{6}$

Households also behave in a gradual manner when adjusting their holdings of durable goods and housing, as do firms when investing in productive capital. But unlike spending on nondurable goods and services, gradual adjustment in these areas manifests

6. Households and firms are much less sensitive to transitory changes in income and sales; for example, the first-year responses shown in table 2 would be roughly halved if the income shift were only temporary. In part, this response results from the life-cycle view of consumer choice built into the model, according to which a temporary blip in household income yields only a small change in the value of lifetime resources. But households and firms are also less willing to respond to changes in income and interest rates viewed as temporary because of habit persistence and adjustment costs. 
itself in the response of capital stocks to the permanent rise in aggregate income and sales: As in the previous example of a change in financial conditions, investment spending responds quickly. Because private investment spending is a major component of aggregate demand, composing almost one-quarter of nominal gross domestic product (GDP), these accelerator effects have important implications for the dynamic response of the overall economy to disturbances. ${ }^{7}$

\section{The Influence of Changes in Output on Inflation}

The final step in the FRB/US transmission mechanism concerns the behavior of inflation. Because of labor contracts and other frictions, wages and prices are slow to adjust to changes in economic conditions. Such "sticky-price" behavior, which is readily apparent in the historical data, is incorporated into the model by making the current rate of aggregate price inflation depend on five factors: (1) the degree to which the markup of prices over unit labor and energy costs is out of line with its historical mean; (2) the recent past rate of price inflation; (3) the rate of growth of unit labor and energy costs expected to prevail in the future; (4) the current and expected degree of slack in labor and product markets; and (5) movements in the relative prices of food, energy, and imports. ${ }^{8}$

In the model, inflation is predicted to decline as long as labor and capital are underutilized and to rise whenever resource utilization is above average. Diagram 1 illustrates this behavior. The FRB/US model

7. Business inventory decisions tend to augment these accelerator effects because the desired stock of inventories is proportional to the level of aggregate sales. This relation implies that a permanent jump in spending leads to a temporary surge in stockpiling that quickly fades. Another area in which spending responds in a hump-shaped pattern is imports, which rise almost 2 percent in the first year after a sustained jump in GDP but then fall back to only 1 percent. In contrast to investment spending, the response of imports to shifts in domestic activity acts as a stabilizing force for the U.S. economy by diverting a portion of any increase in domestic demand to foreign firms. This stabilizing property of import demand is even greater in many other models of foreign trade because they do not impose the equilibrium condition of stable long-run import shares of GDP but allow the long-run income elasticity of imports to be 2 or higher.

8. Aggregate wages are determined in a similar manner, in that wage inflation depends primarily on past wage inflation, expected future growth in consumer prices and labor productivity, and aggregate resource utilization. Wage inflation is also influenced by changes in the minimum wage and payroll taxes. Taking the wage and price equations together, the FRB/US specification of the inflation process is in certain respects similar to the traditional "Phillips curve" model; however, unlike a Phillips curve, it is derived from optimizing behavior and explicitly accounts for the effects of expectations.
1. Partial equilibrium effect on inflation of a reduction of 1 percentage point in the unemployment rate

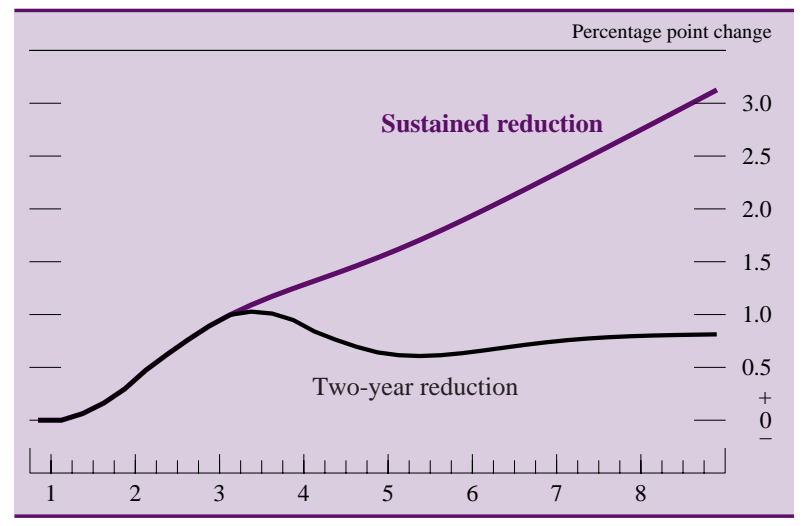

predicts that, all else being equal, if the unemployment rate is held 1 percentage point below its equilibrium level on a sustained basis, inflation should climb steadily about 0.4 percentage point a year, provided that the public's expectations for long-run inflation rise gradually in response to the actual pickup in inflation. Alternatively, if the decline in unemployment is temporary, lasting only two years, then the long-term change in the rate of inflation is limited, settling in at about 0.8 percentage point.

These partial-equilibrium simulation results have two important implications for monetary policy in the context of FRB/US. The first concerns the absence of a long-run tradeoff between the level of unemployment and that of inflation. Because inflation stabilizes only if unemployment returns to its equilibrium level-a property known as the natural rate hypothesis-long-run economic stability requires real interest rates and other financial conditions to be consistent with a balance between aggregate spending and the productive potential of the economy. For this balance to be achieved, in the long run the nominal value of the federal funds rate must be set to reflect both the prevailing rate of inflation and the underlying determinants of spending and production.

The second implication for policy concerns the cost of altering the rate of inflation. If the prevailing rate of inflation has risen because of past episodes of over-utilization of resources or other disturbances directly boosting inflation, then a return to the original inflation rate requires a period of tight monetary policy - that is, for a time, the level of the real funds rate must be elevated above its long-run equilibrium level, causing the unemployment rate to be temporarily above its equilibrium level. If inflation has fallen, then the opposite holds: Restoration of the previous growth rate of prices allows a period of low real interest rates and above-average employment. 


\section{Full-Model Effects of an Easing in Monetary Policy}

So far the analysis of the FRB/US transmission mechanism has dealt with each of its components in isolation from one another. Now we can put the pieces together and show how the transmission mechanism functions in its entirety by examining the way a drop in the federal funds rate, acting through sector-specific responses to induced changes in financial conditions and income, works to influence aggregate output, unemployment, and inflation.

Table 3 summarizes the simulated response (expressed relative to baseline) of the full FRB/US model to a policy action that lowers the federal funds rate by 1 percentage point on a sustained basis. In this simulation, the public initially interprets the drop in the federal funds rate as a temporary action that will be reversed relatively quickly. Thus, their expectations for the future are little changed at first. As time passes, however, the public interprets the easier stance as a signal that the long-run objectives of monetary policy have changed and that policymakers seek to raise the level of inflation permanently. For this reason, beliefs about the future are revised more and more as the reduction in the funds rate is sustained.

The evolving nature of expectations explains why the 1 percentage point decrease in the funds rate initially leads to only a small drop in long-term interest rates (upper portion of table 3). As investors come to believe that the policy easing represents a long-term shift in policy objectives, they gradually revise down their estimate of the average level of short-term interest rates likely to prevail over the next ten years. As a result, bond yields are $1 / 2$ percentage point below baseline by the end of two years. ${ }^{9}$ Arbitrage considerations cause this fall in bond yields to affect other asset markets and to lead both to higher stock prices and to a depreciation of the dollar. ${ }^{10}$

The improvement in financial conditions stimulates activity in various sectors and leads to an

9. The decline in bond yields is also limited by the public's expectation that nominal short-term interest rates, after falling for an extended time, will eventually recover and then increase by the amount of the revision to the expected long-run rate of inflation.

10. In this simulation and throughout most of the article, it is assumed that the public forms its expectations about the future course of the economy using a small-scale forecasting system that includes output, inflation, the federal funds rate, an estimate of the economy's long-run equilibrium real short-term interest rate, and an estimate of the long-run trend level of inflation sought by policymakers. This particular characterization of expectations is discussed in Brayton and others, "The Role of Expectations in the FRB/US Macroeconomic Model.",
3. Monetary transmission mechanism in the FRB/US model: Full-model simulated effect of a 1 percentage point fall in the federal funds rate

Percent

\begin{tabular}{|c|c|c|}
\hline \multirow{2}{*}{ Item } & \multicolumn{2}{|c|}{ Response at end of year } \\
\hline & 1 & 2 \\
\hline & \multicolumn{2}{|c|}{ Change from baseline } \\
\hline \multicolumn{3}{|l|}{ Financial markets } \\
\hline Yield on 10-year Treasury bonds & -.3 & -.5 \\
\hline Stock market prices ............ & 8.8 & 12.7 \\
\hline Exchange rate value of the dollar & -2.2 & -4.9 \\
\hline \multicolumn{3}{|l|}{ Aggregate activity } \\
\hline GDP (chain-weighted 1992 dollars) & .6 & 1.7 \\
\hline Unemployment rate $\ldots \ldots \ldots \ldots \ldots$. & -.2 & -.7 \\
\hline \multirow[t]{2}{*}{ Consumer price inflation rate } & .2 & .6 \\
\hline & \multicolumn{2}{|c|}{ Portion of total response } \\
\hline \multicolumn{3}{|l|}{$\begin{array}{l}\text { Decomposition of GDP response into } \\
\text { expenditure categories }{ }^{1}\end{array}$} \\
\hline Consumer spending, durable goods (8.3) & 24.0 & 18.6 \\
\hline Consumer spending, other $(59.4) \ldots \ldots$. & 28.0 & 26.2 \\
\hline Business fixed investment (10.6) & 13.0 & 18.5 \\
\hline Residential investment (4.0) .... & 26.2 & 24.0 \\
\hline Inventory investment $(0.8)$. & 16.4 & 10.7 \\
\hline Exports $(11.9) \ldots \ldots \ldots \ldots$ & 7.1 & 13.0 \\
\hline Imports $(-13.1)$ & -17.5 & -14.8 \\
\hline Government (17.9) & 2.4 & 3.4 \\
\hline \multicolumn{3}{|l|}{$\begin{array}{l}\text { Decomposition of GDP response } \\
\text { into transmission channels }\end{array}$} \\
\hline Cost of borrowing $\ldots \ldots \ldots$ & 26.9 & 36.4 \\
\hline Stock market ...... & 16.0 & 20.7 \\
\hline Exchange rate value of the dollar & 6.9 & 17.3 \\
\hline Anticipated nonfinancial responses & 50.2 & 25.7 \\
\hline \multicolumn{3}{|l|}{$\begin{array}{l}\text { Decomposition of inflation response into } \\
\text { transmission channels }\end{array}$} \\
\hline Resource utilization & 10.6 & 33.1 \\
\hline Exchange rate value of the dollar & 24.8 & 22.4 \\
\hline Anticipated nonfinancial responses & 64.6 & 44.5 \\
\hline
\end{tabular}

1. 1997 nominal shares of GDP in parentheses.

increase in the level of real GDP. This increase is initially modest, but as adjustment proceeds and accelerator effects kick in, the response of aggregate spending quickens, and by the end of two years, real GDP has risen about 13/4 percent above its baseline level. As suggested by the earlier discussion of financial influences on spending, investment spending accounts for a disproportionate share of the increase in GDP (table 3, lower portion). For example, at the end of two years the change in residential investment accounts for about one-quarter of the increase in output even though it constitutes only 4 percent of aggregate spending, and the portions of the GDP response attributable to outlays on consumer durable goods and business fixed investment are roughly twice their expenditure shares. Inventory investment also plays a disproportionate role in the rise of aggregate demand.

Another way to decompose the GDP response is to break it down into its primary transmission channels-that is, the separate effects on spending of changes in the cost of borrowing, stock market 
wealth, and the exchange rate discussed earlier, as well as a fourth channel, anticipated nonfinancial responses. In the model simulation, changes in the funds rate exert a direct influence on expectations of future movements in output and inflation. In essence, this influence can be thought of as an anticipation of the effects of the other three channels on aggregate activity that have yet to materialize. For this reason, the importance of this anticipatory channel fades as the direct effects of the other channels emerge in full and expectations of future conditions are realized in actual developments.

But the anticipations channel is powerful in the short run, and it accounts for about half of the total response of aggregate output in the first year (lower portion of table 3). By contrast, only a quarter of the first-year GDP response is directly attributable to current and past declines in the cost of borrowing; wealth effects and dollar depreciation account for even smaller shares. By the second year, the importance of anticipated changes in aggregate income and other variables that have not yet materialized is considerably diminished. Commensurately, that of the three standard channels is raised-particularly the exchange rate channel, where adjustment of trade flows to dollar depreciation is especially drawn out.

As with the GDP response, the movement in aggregate price inflation can also be decomposed into its primary determinants, including a channel that measures the anticipated effect of the policy easing on expected changes in the future growth rate of trend unit production costs that have yet to emerge. Such anticipation effects-related in part to the public's evolving view of the long-run rate of inflation sought by policymakers-are extremely important in the short run and account for almost half of the two-year change in actual inflation. However, their effect by the end of the third year-not shown in table 3-is zero. The contribution of current and past changes in resource utilization is also considerable, as is that of exchange rate depreciation. The latter arises because a large portion of the induced decline in the foreign exchange value of the dollar is passed through into the dollar-denominated price of imports, which in turn directly boosts consumer prices.

\section{SOME MACROECONOMIC CONSEQUENCES OF AGGREGATE DISTURBANCES}

The preceding discussion showed how policy actions are transmitted throughout the economy, affecting real variables, such as consumption and output, and nominal variables, such as inflation. This section looks at the monetary mechanism in a slightly different way by examining monetary policy responses to disturbances originating from elsewhere in the economy. These experiments show that the way in which monetary policy reacts to shocks, together with the nature of the shock itself, influences the way in which the economy evolves over time.

Simple macroeconometric models have only a few possible types of disturbances, often just generic shifts in aggregate demand and supply. But in a larger model like FRB/US, as well as in the real world, the kinds of disturbances are numerous (see box "On Defining and Measuring Shocks"). In this section, the focus is on the implications for policy of two general classes of disturbances: shocks whose primary initial influence is on spending ("demand" disturbances) and shocks whose initial effect is mainly on prices or production ("supply" disturbances). All shocks differ, and their classification is not always straightforward. There are, however, some broad similarities of disturbances within a class and important differences in the policy implications of each type of shock.

\section{A Shift in the Equity Premium}

As just noted, demand shocks include any disturbance directly affecting people's willingness to spend. In FRB/US, shifts in foreign demand, personal income taxes, and asset prices are examples of demand disturbances. In regard to the last example, movements in stock market wealth that are not explained by changes in interest rates and other fundamentals are frequent occurrences. These may occur because people suddenly reassess the riskiness of the stock market and demand a higher or a lower rate of return for holding equities relative to bonds. This reassessment is called a change in the equity premium.

For illustrative purposes, we use the FRB/US model to simulate a permanent rise in the equity premium that is sufficient to bring about an initial 20 percent decline in stock market wealth. Many policy responses to this disturbance could be considered; results for three of them, expressed as changes from baseline, are summarized in diagrams 2 and 3.

Policy cannot completely offset the consequences of the rise in the equity premium for stock prices; so regardless of the policy response, the initial fall in real stock-market wealth is essentially the same (diagram 2, upper-left panel). For consumers, this development represents a significant decline in the wealth that can be allocated to fund current and future expen- 
ditures. For firms, the higher premium implies an increase in the cost of financing capital outlays using equity. The FRB/US model predicts that, in the absence of adjustment costs, consumers would respond to this change in financial conditions by reducing the level of consumption approximately 0.6 percent and firms would cut equipment investment a bit more than 0.8 percent per year. (That is, the frictionless responses to the rise in the equity premium would be identical to the fifteen-year partial-equilibrium changes shown in table 1.) However, neither category of expenditures falls by this amount at first because of the adjustment costs and other frictions discussed earlier (diagram 3, top panels).

Falling demand and the associated rise in unemployment put downward pressure on inflation. Monetary policy can reinforce this effect on output and inflation if it fails to respond to the change in the macroeconomic environment. Because the rise in the equity premium is permanent, it leads to a sustained loss in wealth and a permanent increase in the saving rate. As a result, permanently lower real interest rates are necessary after the shock to restore equilibrium. Thus, if the nominal federal funds rate were kept constant, the initial value of the real federal funds

\section{On Defining and Measuring Shocks}

In the context of a model, a disturbance is any factor affecting spending and other variables that is not itself determined by the equations of the model — that is, any factor exogenous to the system. These exogenous factors fall into two categories. The first includes all explanatory variables determined outside macroeconomic models, such as population growth. The second category includes the errors-the difference between the model's predictions and actual historical outcomes-made by the model's equations. This definition of shocks makes it clear that the decomposition of movements in economic data into the portion explained by a model's structure and the portion attributable to autonomous influences depends on the model used in the analysis.

For example, in the FRB/US model, movements in the relative price of oil are treated as autonomous and not affected by changes in energy use and production. However, a model of greater complexity might include equations for the world demand and supply of petroleum and thus would attribute at least some changes in the price of oil to factors internal to the model, rather than classifying them as disturbances. Similarly, FRB/US and other models with a fully articulated supply side distinguish between exogenous changes in prices and autonomous disturbances to productivity. However, in smaller models that lack an aggregate production function, such as the IS-LM-Phillips-curve system of many textbooks, the wage-price block is often simply called a short-run supply curve, and price disturbances are therefore frequently referred to as supply shocks. ${ }^{1}$

The measurement of shocks is also influenced by empirical methodology, as illustrated by research in the early 1980s that suggested that permanent shocks to supply are important in explaining movements in real GDP. The relative importance and the persistence of supply and demand shocks remain subjects of considerable research and

1. See Laurence Ball and N. Gregory Mankiw, "Relative-Price Changes as Aggregate Supply Shocks," Quarterly Journal of Economics, vol. 110 (February 1995), pp. 161-93. debate. ${ }^{2}$ Such uncertainty over the duration of disturbances complicates monetary policy because of the significant lag between changes in the federal funds rate and the response of aggregate output, unemployment, and inflation. Thus, policymakers must often act before they have complete information; for example, in the case of an unexplained movement in equity prices, they must act without knowing how long the bull or bear market will last.

Finally, the definition and measurement of shocks is influenced by the theoretical approach used to construct the economic model. New Keynesian models such as FRB/US allow for direct disturbances to many sectors of the economy without inquiring too closely into the exact nature of these disturbances. ${ }^{3}$ By contrast, another class of modelsknown as dynamic stochastic general equilibrium, or DSGE, models - are based on the view that the economy is subject to only a small number of fundamental disturbances to consumer tastes and production technology. ${ }^{4}$ Such models place more importance than do New Keynesian models on the role of productivity shocks in explaining economic fluctuations. These models also interpret historical responses of output and employment to disturbances as people's optimal adjustments, rather than as a failure of markets to clear. Accordingly, DSGE models assign a much smaller role to monetary policy in mitigating the effects of macroeconomic disturbances than do New Keynesian models like FRB/US.

2. See Charles R. Nelson and Charles I. Plosser, "Trends and Random Walks in Macroeconomic Time Series: Some Evidence and Implications," Journal of Monetary Economics, vol. 10 (September 1982), pp. 139-62, and Pierre Perron, "The Great Crash, the Oil Price Shock, and the Unit Root Hypothesis," Econometrica, vol. 57 (November 1989), pp. 1361-401, for examples of research into the permanence of supply shocks.

3. One consequence of this approach is that a real-world event may manifest itself as a set of simultaneous disturbances to different portions of the model. For example, the recent Asian financial crisis appears as an autonomous decline in foreign output, a reduction in relative oil prices, an unexpected appreciation of the dollar, and a fall in the premium incorporated into U.S. bond yields.

4. For an introduction to DSGE models, see Edward Prescott, "Theory ahead of Business Cycle Measurement," Federal Reserve Bank of Minneapolis Quarterly Review, vol. 10 (Fall 1986), pp. 9-21. 
rate would be too high (diagram 2, lower-right panel). The high real rate would put additional downward pressure on aggregate spending and thereby raise unemployment and push down inflation (diagram 2, middle-left and middle-right panels respectively). As a result, the real funds rate would rise further. If allowed to persist, this policy would result in a continuing downward spiral of falling output and inflation, driven by ever-rising real interest rates.

An alternative policy is to fix the real interest rate at its initial level. The lower-left panel of diagram 2 shows a substantial decline in the nominal funds rate associated with this policy (curve for fixed real funds rate). As already noted, however, a recovery in aggregate demand requires that the real interest rate fall.
Thus, fixing the real rate is also destabilizing in the long run. Therefore, in response to a demand shock, and in the absence of some additional countervailing disturbance, the real rate must be moved in the same direction as the movement in demand resulting from the equity shock.

One policy response that fits this description is shown by the curve for stabilizing policy in the lower-left panel of diagram 2. The reduction in the funds rate shown is small but long lasting and so is sufficient for bringing inflation and unemployment back to their previous levels. The mechanism through which this policy works is that described previously in the full-model simulation of the effects of an easing in policy: According to the FRB/US model, a

2. A permanent increase in the equity premium (deviation from baseline)

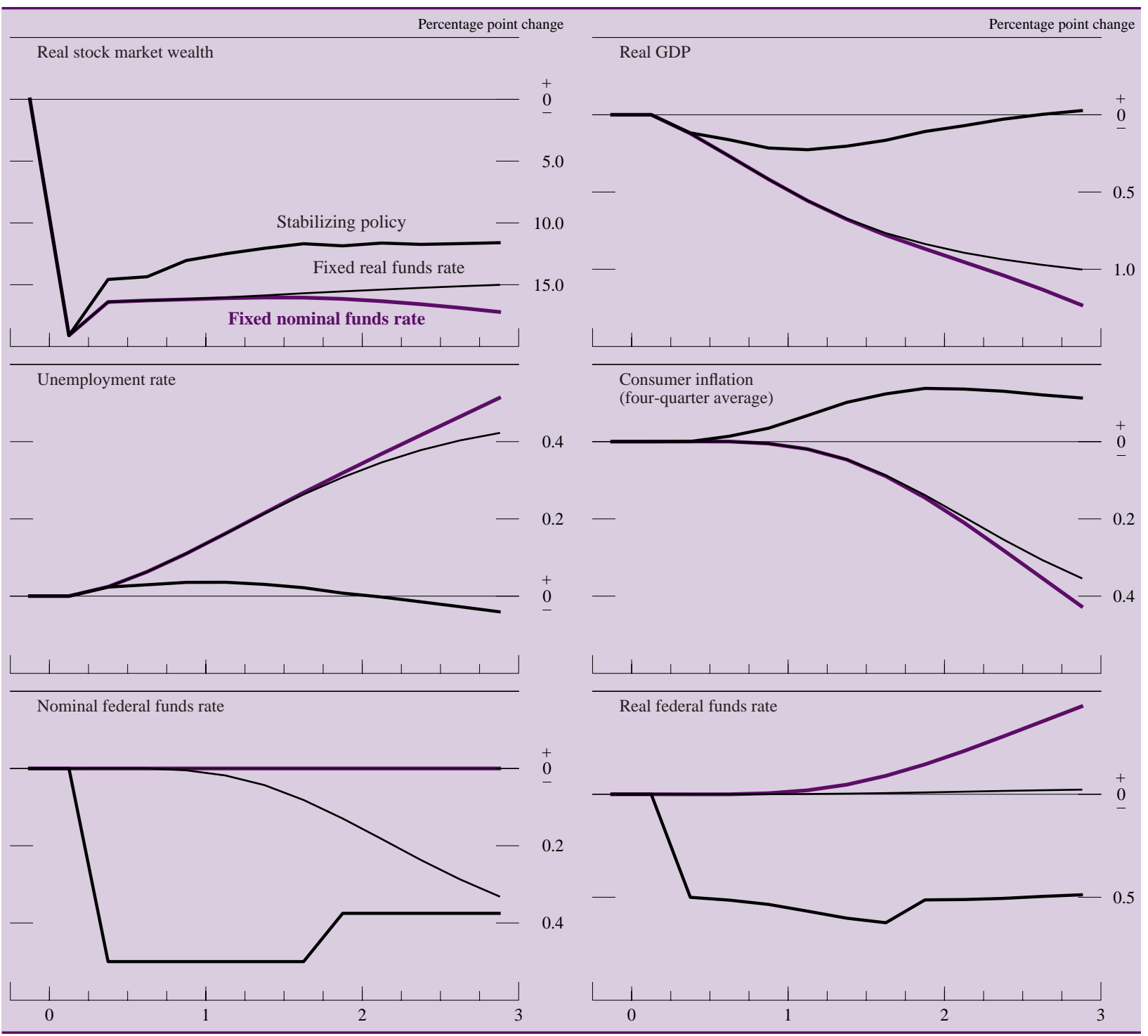


3. A permanent increase in the equity premium and the components of spending (deviation from baseline)

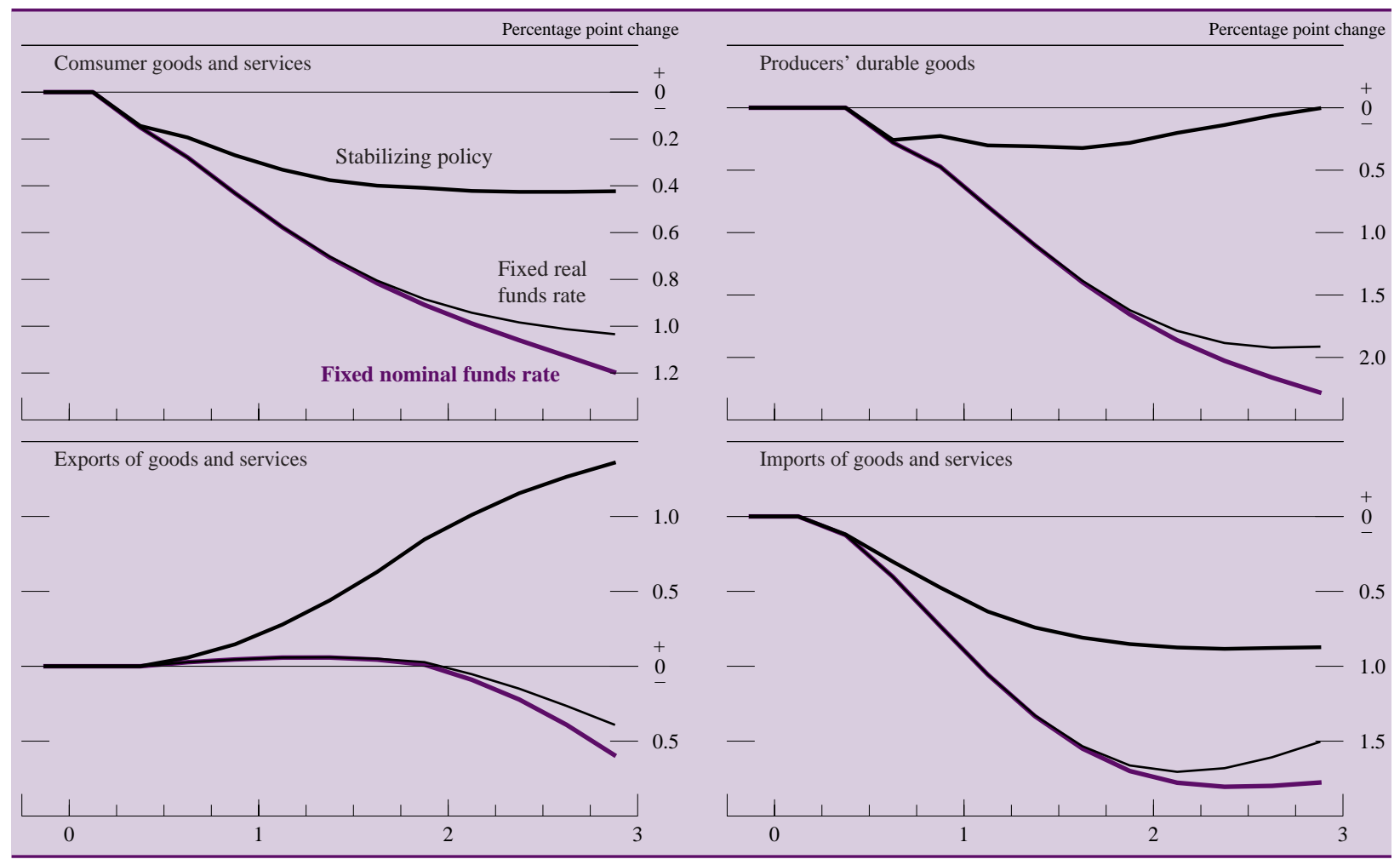

reduction in the federal funds rate today lowers real interest rates today and generates expectations of lower rates and of higher output in the future. These expectations, in turn, elicit higher domestic spending by raising the target level of consumption and investment spending. These effects are supplemented by an expectations-driven decrease in corporate bond rates, which helps the stock market recover some of its initial losses. ${ }^{11}$ Finally, the reduction in domestic interest rates puts downward pressure on the exchange value of the U.S. dollar, improving international competitiveness and strengthening the trade balance (diagram 3, bottom panels).

The stabilizing policy promptly returns both inflation and resource utilization close to their original levels. Only a brief, small acceleration in inflation

11. The value of stock-market wealth recovers somewhat in the quarter immediately following the shift in the equity premium because of expectations on the part of bond-market participants that the initial loss of wealth will reduce the equilibrium real interest rate. Equity prices rise in response to this expectation because of asset arbitrage. Beyond the first quarter or two, expected real corporate bond rates fall because of expectations of lower short-term nominal interest rates in the future and sluggish adjustment of price inflation. This fall permits the modest recovery in stock market wealth to persist. However, when the nominal federal funds rate is held fixed, once expectations of declines in the federal funds rate go unrealized, stock market wealth begins to fall once again. and a slight increase in unemployment are borne by the economy. The increase in inflation is attributable to exchange-rate pass-through, for the fall in the dollar also leads to higher prices of imported consumer goods, which are then passed through into a higher rate of consumer price inflation. For the most part, this ability to offset simultaneously the output and the inflation consequences of demand disturbances is a feature of the FRB/US model, and of all models of its class: Stabilizing both output and inflation are complementary objectives in the presence of a shift in aggregate demand.

As diagram 2 shows, there is a monetary policy setting associated with a path for the real interest rate that stabilizes inflation and unemployment. However, under this policy, consumer expenditures are significantly lower throughout the period shown in the upper-left panel of diagram 3 and for the period beyond. Thus, monetary policy cannot fully replace the loss of wealth and consumption caused by the rise in the equity premium. This result illustrates the general principle that in the long run policy can only restore normal levels of resource utilization and determine the prevailing rate of inflation; it cannot undo all the effects of permanent shifts in fundamentals. 


\section{An Acceleration in Wage Compensation}

In contrast to demand shocks, some macroeconomic disturbances affect prices directly and only afterward have an influence on real quantities. Shocks in this category include autonomous movements in the prices of food and energy. Such shocks, together with direct disruptions to the supply of labor or other aspects of production, present policymakers with short-term tradeoffs not encountered in the case of demand shocks.

One typical example of a price shock is an unanticipated change in wage compensation. This change may occur for a number of reasons: In the context of a macroeconomic model, the precise origin of shocks is not always clear. For present purposes it suffices to consider an autonomous temporary acceleration in wage inflation without any accompanying shocks to aggregate demand, labor supply, or the like. For this experiment, the shock raises the four-quarter wage inflation rate by 1 percentage point after a year. Having established that there are circumstances under which pegging either nominal or real interest rates leads to macroeconomic instability, we restrict our attention to policies that stabilize either unemployment or inflation. Simulation results are shown in diagram 4.

As expected, the wage-growth disturbance acts directly and immediately on wages and prices and then on measures of real activity. And as before, monetary policy cannot realistically offset the initial effects of the shock: Wage inflation rises by essen-

4. Transitory increase in wage compensation (deviation from baseline)

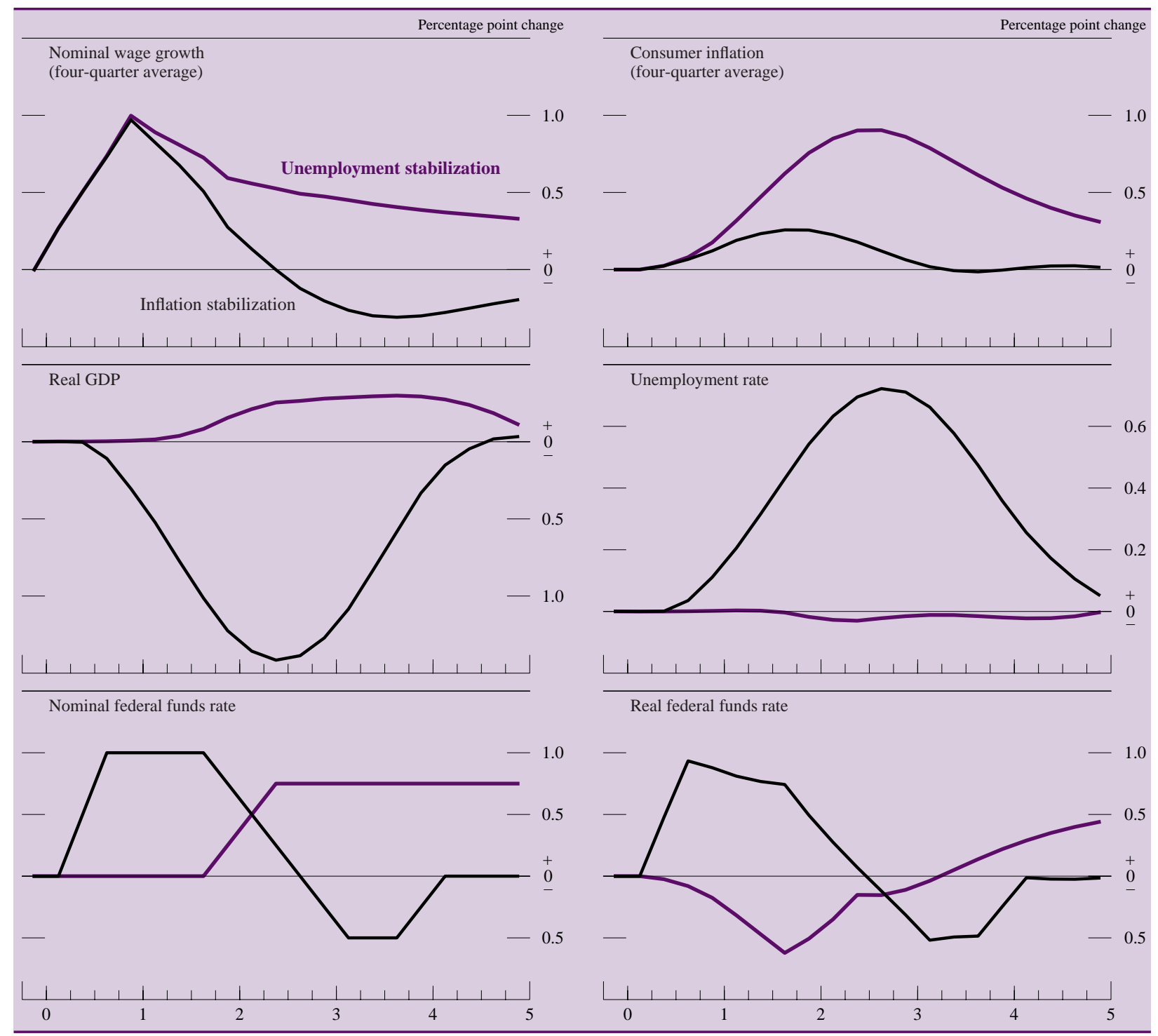


tially the same amount over the first year of the scenario, regardless of the policy responses considered (diagram 4, upper-left panel). All else being equal, the acceleration in wages squeezes the profit margins of firms, inducing a wage-price spiral as firms push up prices in an attempt to re-establish their profit margins. A policy of keeping the inflation rate close to its original level must therefore raise the nominal (and real) federal funds rate early and by a substantial amount (the curves for inflation stabilization, bottom panels). This policy tightening results in an extended period of higher unemployment (middle-right panel). Over time, expectations of future price and wage inflation are brought into line with policy objectives, and real variables return to equilibrium levels.

The depiction of the economy when policy attempts to stabilize unemployment contrasts sharply with the inflation-stabilization case. Because unemployment is slow to respond to falling profit margins, under this strategy the federal funds rate initially remains unchanged (bottom-left panel). The shock therefore propagates into higher and longer-lasting inflation than is the case when policy reacts promptly to head off an emerging wage-price spiral (topright panel). Under this policy, only when growing demand pressure begins to show up in employment do nominal interest rates rise, and then only enough to maintain unemployment near its baseline level (middle-right panel). By this time, the experience of higher inflation has become entrenched in expectations.

Beyond the end of the period shown, price and wage inflation do not return to their original levels: Without an active effort by the monetary authority to contain the actual and expected growth of prices at the original low rates, inflation tends to drift with whatever relative-price disturbances hit the economy. This result is a direct consequence of the natural rate hypothesis embedded in the FRB/US and most other models. For all such models, full employment is consistent with any constant inflation rate, and for the economy to arrive at a particular inflation rate, the monetary authority must take appropriate actionthat is, it must establish a nominal anchor. ${ }^{12}$

12. An extensive literature compares the virtues of possible nominal anchors, which include the price level, the nominal exchange rate, commodity prices, nominal income, and the inflation rate. For a general discussion of this issue, see Bennett T. McCallum "Issues in the Design of Monetary Policy Rules" in John B. Taylor and Michael Woodford, eds., Handbook of Macroeconomics (North-Holland, forthcoming). A readable guide to inflation targeting is Ben S. Bernanke and others, Inflation Targeting: Lessons from the International Experience (Princeton University Press, 1999).

\section{A Shift in the Level of Productivity}

Besides being subject to shifts in relative prices, the economy is affected by disturbances to the availability or efficiency of inputs to the production process. Changes in labor supply, crop failures, and technological innovations are common examples of such shocks to supply.

A supply disturbance that economists often study is a shift in total factor productivity-that is, an unanticipated change in the volume of output that can be produced with a given level of productive inputs. Some implications of a temporary slowdown in productivity growth are illustrated in diagram 5. In the simulation, the slowdown gradually reduces the level of potential output 1 percent over two years, after which productivity growth returns to normal but the level of potential output remains permanently lower (upper-right panel). One reason for such a decline in productivity might be that research and development expenditures temporarily yield an abnormally low flow of technical innovations.

Two policy responses to such an event are considered. In one, policy acts to bring inflation promptly back to its original level, and in the other, policy stabilizes inflation more gradually. In either case, policymakers and the public are assumed to understand that the reduction in the level of productivity is permanent.

The effect of this shock on real GDP can be split into two parts. First, the level of potential output falls by 1 percent, so that if resource utilization does not change, the level of real GDP must fall proportionally. Second, the other dynamic aspects of adjusting spending behavior cause the initial decline in outlays to be greater than that of potential output, with the result that unemployment rises.

On the price side, the fall in productivity reduces the equilibrium real wage by 1 percent. Reestablishment of labor market equilibrium requires that the real wage fall to this new equilibrium level; monetary policy influences whether the reduction in the real wage occurs through a period of low wage growth, of higher price inflation, or a combination of both.

For monetary policy to keep price inflation close to its original level (curve for rapid stabilization of inflation, middle-right panel), the nominal federal funds rate needs to rise immediately and by a substantial amount (lower-left panel). Raising the funds rate in this way counteracts the expectation that some of the adjustment in real wages will take place through higher prices.

With this policy response, the upward pressure on prices is short-lived. The decline in productivity 
5. Temporary reduction in productivity growth (deviation from baseline)

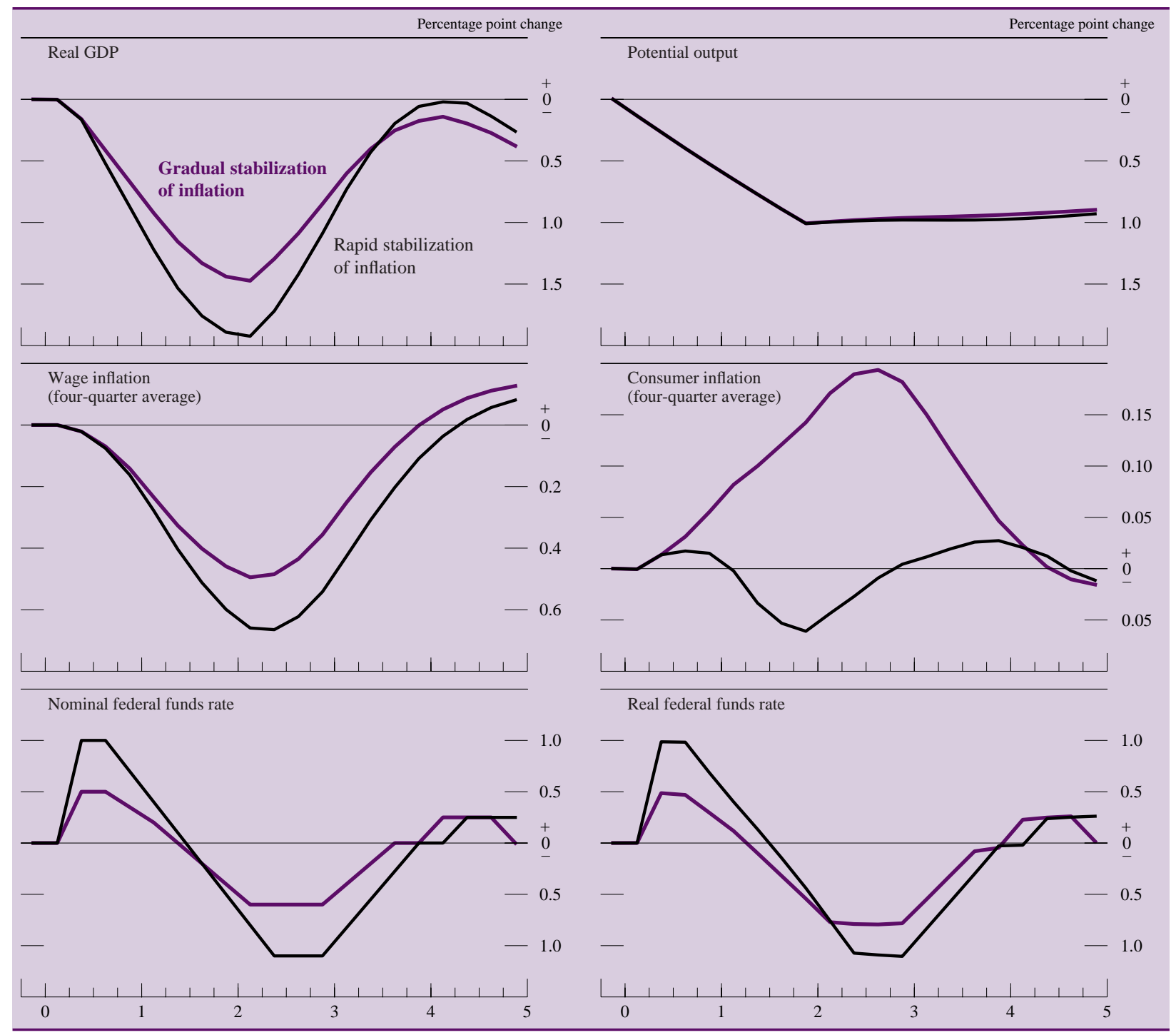

reduces the desired capital stock, bringing down investment. Similarly, the falling real wage reduces labor income, bringing down consumption. The accelerator mechanisms discussed in the previous section tend to make producers' durable equipment and consumption expenditures overshoot their new, lower long-run levels. Accordingly, significant excess supply emerges by the second year.

The initial tightening in policy thus gives way shortly thereafter to substantial easing to support aggregate demand and contain emerging expectations of disinflation. In the end, the policy succeeds in achieving tight control of inflation but at the cost of sizable swings in output around potential.

This policy response is just one of many that are consistent with keeping the inflation rate from drifting over long periods of time. In the diagram, the curves for gradual stabilization show another, more gradual response to the shift in potential output. The early tightening of policy in this case is designed to be one-half the size of the tightening just discussed, as measured by the nominal funds rate. This policy results in more of the real wage adjustment taking place through prices, rather than through nominal wages. It also results in less short-run fluctuation in aggregate spending (upper-left panel). Finally, this less-aggressive policy results in less variability of the nominal federal funds rate throughout the period.

These alternative policies show that, in the context of the FRB/US model, policy that seeks to stabilize inflation must establish a nominal anchor in the long run, but doing so still leaves considerable latitude for different short-run responses to disturbances. In the case of supply shocks (broadly defined to include 
price disturbances), policies that work aggressively against movements in inflation do so at the expense of greater variability in output and interest rates. In contrast, policies that are less strict about short-run control of inflation result in lower variability of output and interest rates by accepting larger fluctuations of inflation. Thus, although there is no long-run tradeoff between the level of employment and that of inflation, supply shocks in the FRB/US model do present policymakers with tradeoffs in variability among output, inflation, and interest rates.

\section{Economic Disturbances and General Policy Responses}

The disturbances discussed above are merely three among the many whose economic effects can be simulated using the FRB/US model. The macroeconomic consequences of a selection of these shocks, including the three just presented, are summarized in table 4. Some of these disturbances-a fall in stock market wealth, a rise in foreign output, and a change in fiscal policy - can be classified as demand shocks. Others-higher wage inflation, a fall in productivity, an increase in oil prices, and a hike in the minimum wage-are examples of supply disturbances. Still others-a depreciation of the dollar and a decline in the relative price of capital goods - combine features of both types of shocks in that they directly affect both spending and production (or prices).

To simplify the comparison of results across the different disturbances, the effects of each disturbance are first simulated holding the real federal funds rate constant (table 4, left-hand portion). Comparing results for the various disturbances reveals a range of macroeconomic outcomes, indicating that each shock has its unique influence on the economy. The results also provide guidance on the direction of the change in the federal funds rate that would be needed to stabilize employment or inflation or both in the model, as well as a rough sense of which shocks would require greater or smaller shifts in the stance of policy.

In theory, individualized policy responses could be crafted to accompany each specific disturbance, with the goal of delivering particular macroeconomic outcomes, subject to the limitation that policy cannot eliminate all short-run fluctuations in both aggregate employment and inflation in the case of supply shocks. In practice, however, the economy often experiences several disturbances at the same time; in addition, policymakers and the public alike may find it difficult to identify the precise nature of shocks as they occur. For this reason, it is useful to consider generalized policy responses that have the property of gradually stabilizing output and inflation in the face of a wide range of economic disturbances.

A simple example of such a policy is the Taylor rule. ${ }^{13}$ According to the rule, the nominal federal funds rate is raised by 150 basis points for each percentage point increase in the rate of inflation. In addition, the rule also increases the federal funds rate by 50 basis points for each percentage point that real GDP exceeds its potential level (a measure usually referred to as the output gap). In the context of the FRB/US model, the rule's procedure for setting the federal funds rate stabilizes the economy for a wide range of macroeconomic disturbances. As shown in the right-hand portion of table 4, the Taylor rule does not ensure that complete stabilization of output and inflation will be achieved in a period as short as three years. Relative to a policy of holding the real funds rate constant, however, the rule does successfully prevent longer-term macroeconomic instability: For all the disturbances, both unemployment and inflation are within 0.1 percentage point of their baseline values after ten years. ${ }^{14}$

\section{MONETARY POLICY AND AVERAGE MACROECONOMIC PERFORMANCE}

The simulations of various disturbances discussed above are examples of the ways in which monetary policy actions affect movements in prices and unemployment after disturbances to aggregate demand and supply. As was noted, disturbances to aggregate demand typically do not present policymakers with a tradeoff between the objective of price stability and that of employment stability: Adjusting the stance of monetary policy to bring the level of economic activity closer to its potential simultaneously acts to damp any upward or downward pressure on inflation. By contrast, production and price disturbances do present policymakers with a tradeoff between the variability of output and that of inflation, though not between the levels: In FRB/US, there is no long-run tradeoff

13. The Taylor rule was introduced "to preserve the concept of ... a policy rule in an environment where it is practically impossible to follow mechanically the algebraic formulas economists write down to describe their preferred policy rules." John B. Taylor, "Discretion versus Policy Rules in Practice" Carnegie-Rochester Conference Series on Public Policy, vol. 39 (1993), p. 197.

14. For many of the disturbances, GDP and the federal funds rate do not return to baseline. Such long-run shifts occur when the shock permanently alters the level of potential GDP or the steady-state rate of interest or both. 
4. Simulated macroeconomic effects of selected disturbances under alternative monetary policies

Percent change from baseline except as noted

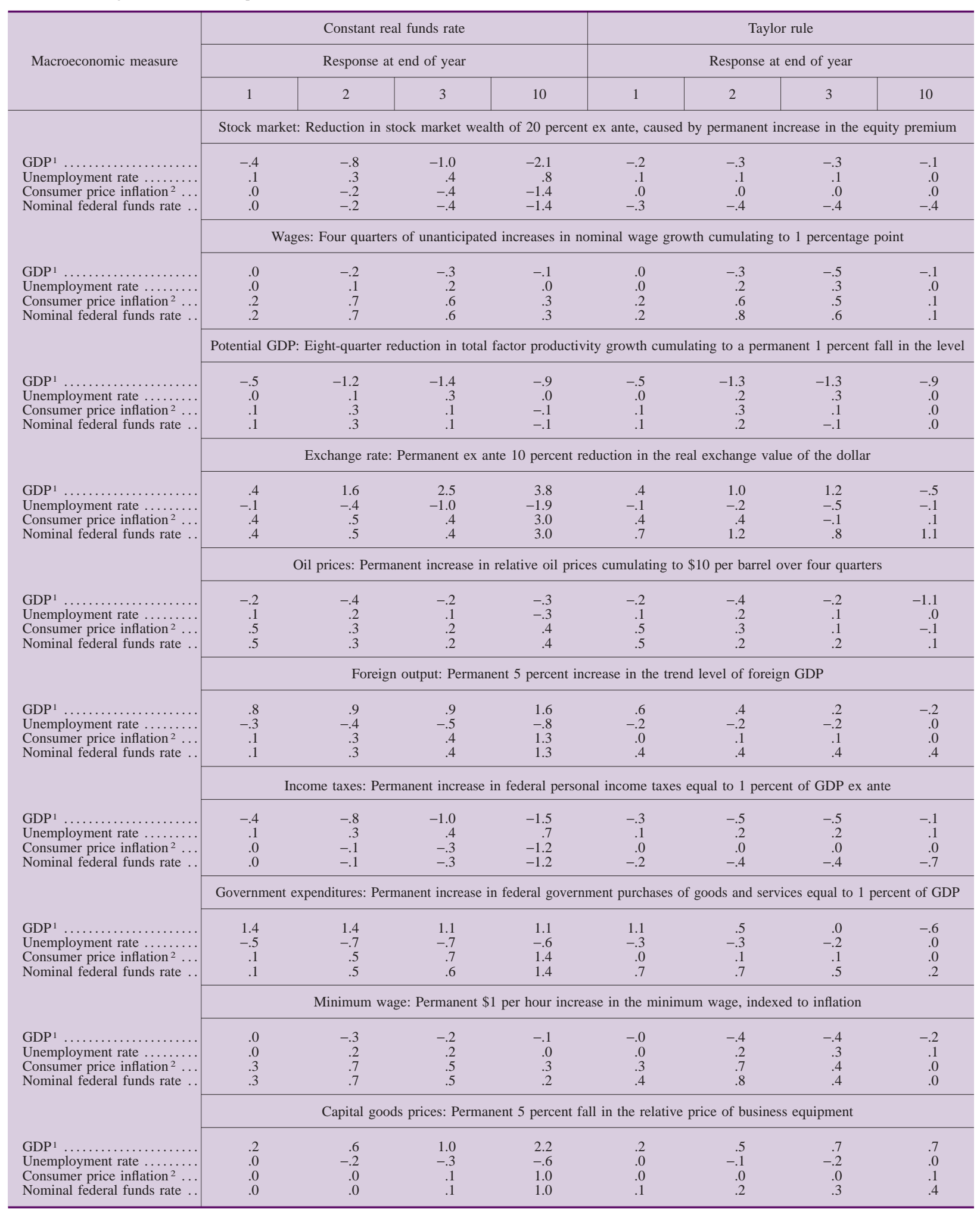

1. Gross domestic product measured in chain-weighted 1992 dollars.

2. Four-quarter growth rate of chain-weighted price index for persona consumption expenditures. 
between unemployment and inflation. ${ }^{15}$ Thus, as seen in the experiment of a negative shock to productivity, a policy that forcefully acts to keep inflation in check achieves this objective at the cost of more pronounced fluctuations in economic activity and unemployment. Alternatively, a more muted initial policy response limits the magnitude of the fall in employment but does so at the cost of larger swings in inflation.

In the context of the full range of demand and supply disturbances hitting the economy, any systematic policy response to changes in macroeconomic conditions embodies its own particular average tradeoff between variability of output and that of inflation. For example, because the Taylor rule discussed earlier responds to movements in inflation and the output gap in a fixed fashion, it generates a predictable stabilization path for different economic measures following any given set of macroeconomic disturbances. Taking account of all the possible shocks that might be encountered over time, and adjusting for their likelihood, one can compute the average variability of output, inflation, and interest rates likely to be experienced under the Taylor rule. Similar calculations can be made for other systematic policy responses-for example, policies that allow for larger or smaller responses to movements in inflation and the output gap or that include responses to past or projected levels of interest, inflation, and other variables.

To analyze the stability implications of the Taylor rule and other systematic policy responses, policy is assumed to follow a generalized policy rule of the form

$$
r_{t}=a+b r_{t-1}+c \pi_{t}+d y_{t},
$$

where $r_{t}$ denotes the federal funds rate in quarter $t$, $\pi$ is the four-quarter inflation rate, $y$ is the output gap, and $a, b, c$, and $d$ are the coefficients of the policy rule. The coefficients of such a generalized policy rule determine how quickly and aggressively policy responds both to deviations of inflation from its target rate and to the output gap. ${ }^{16}$ The choice of coefficient values thus affects the volatility of inflation and output in the economy. For example,

15. In the model, there is a limited long-run effect of inflation on the level of real GDP because the tax system is not neutral in relation to the average rate of inflation. Thus, a change in the average rate of inflation affects the after-tax cost of capital, investment, and potential GDP.

16. For the Taylor rule, $b=0, c=1.5, d=0.5$, and the intercept $a$ depends on the economy's equilibrium real interest rate and the long-run rate of inflation sought by policymakers. policies that respond aggressively to inflation-that is, ones for which the value of $c$ is large-will be associated with a lower average volatility of inflation. The coefficient $b$ on the lagged funds rate measures to what extent the current setting of the funds rate depends on past observations of inflation and output.

The FRB/US model can be used to evaluate the relationship between policy and macroeconomic fluctuations. With a specific set of coefficient values for the generalized policy rule, one can compute the standard deviations of inflation and the output gap associated with that specific policy rule, based on stochastic simulations in which the FRB/US model is repeatedly subjected to random supply and demand shocks based on the experience of the past thirty years. ${ }^{17}$ The shocks include random disturbances to the labor, goods, financial, and foreign markets. This process is then repeated for many different sets of policy coefficients.

Diagram 6 summarizes the results of this experiment. The shaded area shows the inflation and output volatilities that result from choices of coefficients in the generalized policy rule, subject to a constraint that the variability of the federal funds rate does not exceed a specified level. ${ }^{18}$ This limit on funds rate variability serves the purpose of excluding from the analysis "unreasonable" policy rules that are highly effective in offsetting aggregate disturbances (in particular those to demand) but, in so doing, generate wild swings in interest rates. For purposes of these simulations, we assume that the public is fully aware of the policy in place and forms expectations consistent with that policy and the structure of the model. ${ }^{19}$ In addition, the long-run inflation goal of policymakers is assumed to be constant.

In general, points in the lower left portion of the shaded region represent better outcomes, in terms of a lower variability of both inflation and output, than

17. For a complete description of the methodology used in this experiment see Andrew T. Levin, Volker Wieland, and John C. Williams, "Robustness of Simple Monetary Policy Rules under Model Uncertainty," in Monetary Policy Rules, John B. Taylor, ed. (University of Chicago Press, forthcoming).

18. In the FRB/US model, the connection between the level of the output gap and the unemployment rate is close. Thus, in terms of the diagram, greater volatility of the output gap implies greater volatility of the unemployment rate around its equilibrium level.

19. Such expectations are called model consistent, and they differ somewhat from those in the previous sections of the article, in which the public was assumed to have an approximate, but not exact, understanding of monetary policy and the workings of the economy in general. In the present context, model-consistent expectations have the advantage of preventing expectational errors caused by the public's misunderstanding of policy procedures-errors that would be unlikely to occur in the long run if policymakers were to adopt standard procedures. 


\section{FRB/US policy frontier}

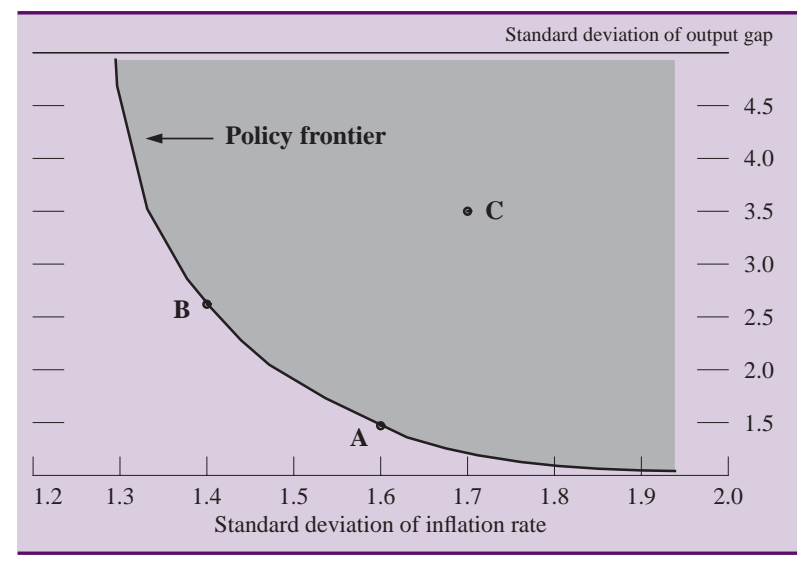

do points in the upper right. The curve on the boundary of the shaded region, labeled "policy frontier," shows the minimum output variability attainable for a given amount of inflation variability. Thus, the frontier represents the best attainable set of outcomes for the types of policy considered here.

Many policies, however, are associated with outcomes well away from the frontier. Modifications to such inefficient policies can lead to outcomes in which the fluctuations of inflation and output are both smaller on average. For example, a policy associated with the outcome labeled point $\mathrm{C}$ in the diagram can be changed so that the resulting outcome is given by point $B$, which represents a lower variability of both inflation and output.

One can draw a number of conclusions from these results. First, among policies on the frontier, there is, as expected, a tradeoff between inflation variability and output variability. As in the examples of shocks to wages and productivity, a policy that decreases the variability of inflation does so at the cost of an increase in the variability of output. As noted, the variability tradeoff stems fundamentally from the existence of supply shocks. Shocks of this type present policymakers with the choice of keeping a tight rein on inflation and accepting large movements in resource utilization or allowing the inflation rate to fluctuate significantly in the short run while tempering the movements in unemployment and output.
Demand shocks, however, present no such conflict: A policy that offsets demand shocks effectively stabilizes both inflation and output. ${ }^{20}$

Not surprisingly, policies that respond relatively aggressively to inflation and only moderately to output generate outcomes of low inflation variability and high output variability. For example, point B on the policy frontier results from a policy that is about 50 percent more responsive to inflation and about 50 percent less responsive to the output gap than the policy associated with point A on the frontier.

A couple of caveats are worth mentioning. First, these results are specific to the FRB/US model; other models may provide different conclusions regarding the existence and characteristics of the tradeoff between inflation variability and output variability. Second, an assumption of the experiment is that the policymaker faces no uncertainty regarding the coefficients or structure of the model and the accuracy of the data, factors that in reality greatly complicate policymakers' decisionmaking. Uncertainties regarding the state of the economy, the "true" model of the economy, and the incidence of supply versus demand shocks may suggest modifications to the types of policy rules considered here. ${ }^{21}$

In summary, this analysis using the FRB/US model shows that, for well-chosen policies, there is a tradeoff between reducing the magnitude of fluctuations in inflation and reducing those in employment and output. Within the set of efficient policies - that is, those associated with the policy frontier-the choice of appropriate monetary policy depends on the weights that policymakers place on stabilizing inflation relative to stabilizing employment.

20. Demand shocks cause a different kind of tradeoff, that between stabilizing inflation and output and minimizing the volatility of movements in interest rates. According to the FRB/US model, to fully offset the effect of all demand disturbances, it would be necessary to regularly raise or lower the federal funds rate by multiple percentage points within a year. Because such violent movements in interest rates may have harmful repercussions on the efficient operation of financial markets, monetary policy in practice is limited to damping the effects of demand disturbances - it cannot eliminate them.

21. For a further discussion of these issues, see John B. Taylor, ed., Monetary Policy Rules (forthcoming). 